\title{
Peran Perawat Sebagai Petugas Surveilans Kesehatan Dengan Perilaku Sehat Ibu Hamil Di Kota Semarang
}

\author{
Much Nurkharistna Al Jihad ${ }^{1}$ \\ Universitas Diponegoro \\ E-mail:jihad.selalu1990@gmail.com
}

\begin{abstract}
Abstrak
Angka Kematian Ibu (AKI) di Indonesia masih tinggi. Berdasarkan hasil Survei Penduduk Antar Sensus (SUPAS) 2015 AKI menunjukkan angka 305 kematian ibu per 100.000 kelahiran hidup(Kemenkes, 2016).Kota Semarang jumlah kematian ibu pada tahun 2015 sebanyak 35 kasus dimana penyebab kematian ibu adalah PEB/eklampsia (34\%), perdarahan (28\%), penyakit (26\%), lain-lain (12\%). Petugas surveilans kesehatan yang telah diterjunkan pemerintah untuk menurunkan AKI termasuk didalamnya adalah perawat.

Jenis penelitian ini adalah penelitian deskriptif dengan studi korelasi dengan pendekatan yang digunakan adalah pendekatan cross sectional. Populasi dalam penelitian ini adalah ibu hamil yang yang berada di 5 kecamatan yang memiliki jumlah kematian ibu tertinggi di Kota Semarang pada tahun 2015 sejumlah 636 orang, besar sampel sejumlah 30 orang.

Hasil penelitian ibu hamil yang masuk pada trimester $2(57,1 \%)$ dan masuk pada trimester $3(42,9 \%)$, didapatkan hasil bahwa 71,4 \% ibu hamil memiliki perilaku yang sehat, 28,6 \% memiliki perilaku tidak sehat.Perawat mampu melaksanakan sebagian perannya dengan baik sebesar 43,3\% dan sebanyak 56,7\% kurang berperan dalam pendampingan ibu hamil.

Perlu adanya perhatian khusus terhadap ibu hamil untuk mencegah terjadinya kematian, program pendampingan ibu hamil oleh petugas surveilans adalah program yang perlu dipertahankan terutama adanya perawat yang menjadi bagian dalam tim gasurkes.
\end{abstract}

Kata Kunci: peran perawat; perilaku sehat; ibu hamil 


\title{
Role of Nurse as Health Surveillance Officer with Healthy Behavior of Pregnant Women In Semarang City
}

\begin{abstract}
Maternal Mortality Rate (MMR) in Indonesia is still high. Based on the results of the Intercensal Population Survey (SUPAS) 2015, AKI showed the number of 305 maternal deaths per 100,000 live births (Kemenkes, 2016). The city of Semarang number of maternal deaths in 2015 were 35 cases where the cause of maternal death was PEB / eklampsia (34\%), bleeding (28\%), illness (26\%), others (12\%). Health surveillance officers who have been deployed by the government to reduce MMR include nurses.

The type of this research is descriptive research with correlation study with approach used is cross sectional approach. The population in this study is pregnant women who are in 5 districts that have the highest number of maternal deaths in Semarang City in 2015 amounted to 636 people, a sample size of 30 people. Result of research of pregnant woman who entered in trimester $2(57,1 \%)$ and entered in trimester $3(42,9 \%)$, got result that $71,4 \%$ pregnant women have healthy behavior, $28,6 \%$ have unhealthy behavior. Nurses are able to perform some of the role well by $43.3 \%$ and as much as $56.7 \%$ less play a role in the accompaniment of pregnant women.

It needs special attention to pregnant women to prevent the occurrence of death, maternity assistant program by surveillance officer is program that need to be maintained especially the existence of nurses who are part of gasurkes team.
\end{abstract}

Keywords: role of nurse; healthy behavior; pregnant mother

\section{Pendahuluan}

Angka Kematian Ibu (AKI) di Indonesia masih tinggi. Berdasarkan hasil Survei Penduduk Antar Sensus (SUPAS) 2015 AKI menunjukkan angka 305 kematian ibu per 100.000 kelahiran hidup(Kemenkes, 2016). Hal tersebut masih jauh dari tujuan Millenium Development Goals (MDGs) yang menargetkan AKI pada tahun 2015 adalah 102 kematian per 100.000 kelahiran hidup. Setelah MDGs berakhir, dilanjutkan dengan Agenda Pembangunan Berkelanjutan atau Sustainable Development Goals (SDGs) tahun 2015-2030 sebagai kesepakatan pembangunan global. Salahsatu tujuan SDGs yaitu menjamin kehidupan yang sehat dan mendorong kesejahteraan bagi semua orang disegala usia. Terdapat 13 target termasuk AKI, dimana target pada SDGs adalah mengurangi angka kematian ibu pada tahun 2030 hingga dibawah 70 per 100.000 kelahiran hidup.

Kematian Ibu di Provinsi Jawa Tengah pada tahun 2015 sebanyak 619 kasus atau sebesar 111,16/100.000 kelahiran hidup. Terjadi peningkatan pada tahun-tahun sebelumnya yaitu tahun 2011 sebanyak 668 kasus, 2012 sebanyak 675 kasus, 2013 sebanyak 668 kasus, 2014 sebanyak 711 kasus. Berdasarkan Audit Pemerintah Jawa Tengah, penyebab kematian ibu disebabkan oleh preeklampsia-eklampsia sekitar 35,26\%, perdarahan 16,44\%, infeksi 4,74\%, abortus 0,30\% dan partus lama 0,30\%.Di Kota Semarang jumlah kematian ibu pada 
tahun 2015 sebanyak 35 kasus dimana menempati urutan kedua Jawa Tengah setelah Kabupaten Brebes. Penyebab kematian ibu didominasi oleh PEB/eklampsia (34\%), perdarahan $(28 \%)$, penyakit (26\%), lain-lain (12\%).

Penanganan yang dilakukan oleh pemerintah Kota Semarang dalam rangka penurunan AKI diantaranya adalah penggunaan Buku KIA pada ibu hamil, pelayanan antenatal terpadu di fasilitas pelayanan kesehatan tingkat dasar dan rujukan, pencegahan dan penanganan bumil resti, pencegahan dan penanganan anemia pada kehamilan, pencegahan dan penanganan Kurang Energi Kronis (KEK) pada kehamilan, pelaksanaan Kelas Ibu Hamil, Prevention of Mother to Child Transmission of HIV (PMTCT), serta program yang terbaru adalah penerjunan tenaga surveilans kesehatan ibu dan anak (Gasurkes KIA). Peningkatan perilaku sehat ibu hamil juga terus diupayakan untuk mencegah terjadinya kematian ibu.

Skinner mengemukakan bahwa perilaku merupakan respons atau reaksi terhadap stimulus atau rangsangan dari luar. Perilaku kesehatan yaitu hal-hal yang berkaitan dengan tindakan atau kegiatan seseorang dalam memelihara dan meningkatkan kesehatannya, termasuk tindakan-tindakan untuk mencegah penyakit, kebersihan perorangan, memilih makanan, sanitasi dan sebagainya.

Perilaku sehat ibu hamil sesuai dengan buku KIA antara lain melakukan pemeriksaan kehamilan (ANC), perawatan sehari-hari, konsumsi makanan dengan pola gizi seimbang, serta mengetahui tanda bahaya kehamilan dan tanda bayi akan lahir. Sedangkan sesuai dengan trimester kehamilan, perilaku sehat ibu hamil meliputi : Trimester I (penerimaan terhadap perubahan fisik dan psikologis trimester I, pemeriksaan kehamilan trimester I, konsumsi makanan seimbang, perawatan gigi dan mulut, istirahat cukup, perawatan payudara), Trimester II (pemeriksaan kehamilan trimester II, nutrisi yang dikonsumsi, hubungan seksual yang aman dan nyaman, general higiene, istirahat, tidur, dan latihan, mengetahui tanda bahaya, tidak merokok, tidak mengkonsumsi alkohol, minum obat sesuai resep), Trimester III (penerimaan perubahan fisik dan psikologis trimester III, pemeriksaan kehamilan semester III, seksualitas yang aman dan nyaman, mengatasi ketidaknyamanan ringan, mengetahui tanda bahaya, nutrisi trimester ketiga, menjaga kebersihan umum, menjaga penggunaan obat, mempersiapkan kelahiran janin, menyusui, serta menjadi orangtua).

Perawat memiliki tugas pokok fungsi menjalankan asuhan keperawatan pada kelompok dengan resiko tinggi salah satunya pada ibu hamil yang memiliki tujuan menyelesaikan masalah kesehatan dan keperawatan mengenai kehamilan. Pada keperawatan kesehatan masyarakat, kesehatan ibu selalu menjadi prioritas utama dengan memperhatikan status 
kesehatan dan kebutuhan ibu hamil, faktor resiko, penyebaran penyakit menular pada ibu hamil, status sosial ekonomi, kebutuhan emosional, fisik dan identifikasi pada depresi post partum (Warner, 2014).

Tenaga surveilans kesehatan (Gasurkes) menjalankan perannya pada tahun 2015 di Kota Semarang dimana perawat menjadi salahsatu unsur tenaga kesehatan yang masuk pada gasurkes. Peran Gasurkes menurut koordinator Gasurkes Tingkat Kota Semarang yaitu pada upaya promotif dan preventif, diantaranya adalah mendata dan memetakan masalah ibu hamil di wilayah binaan masing-masing, mendampingi ibu hamil risiko tinggi dan mengetahui kondisi ibu hamil tersebut secara detail, mendampingi ibu hamil secara terus menerus sampai masa nifas 42 hari setelah melahirkan, memberikan penyuluhan maternal di kelas-kelas ibu hamil yang ada di wilayah binaan masing-masing, melaporkan ke Puskesmas data ibu hamil dan keadaannya secepatnya.

Perawat sebagai tenaga surveilans kesehatan memiliki peran pendampingan pada ibu hamil. Program pendampingan dilaksanakan dengan tujuan untuk meningkatkan kesadaran masyarakat terutama ibu hamil mengenai kesehatan masa kehamilan sebagai bagian dari Kampanye Peduli Kesehatan Ibu pada tahun 2014 dan menghindari keterlambatan penanganan pada kondisi darurat.Kegiatan pendampingan berupa pendampingan pada masa hamil, melahirkan dan nifas yang merupakan implementasi dari Tupoksi bidan serta perawat. Pelaksanaannya terdiri dari pendampingan, peningkatan motivasi dan mengajak ibu hamil melaksanakan antenatal care, bersalin di fasilitas kesehatan, pemanfaatan fasilitas PONED dan PONEK hingga post natal care untuk mengurangi jumlah AKI.

Penelitian tentang peran perawat dalam peningkatan perilaku sehat ibu hamil di Kota Semarang dengan studi petugas surveilans kesehatan perlu dilaksanakan dengan menilai peran perawat yang telah dilaksanakan dan mengkonfirmasikannya secara mendalam guna memperkuat hasil temuan tersebut. Hal ini berguna untuk mengetahui sejauh mana perawat mendapatkan kesempatan dalam pelayanan kesehatan ibu hamil di Semarang.

\section{Tinjauan Teoritis}

Perilaku merupakan totalitas penghayatan dan aktivitas seseorang sebagai hasil bersama atau resultan antara berbagai faktor, baik faktor internal maupun faktor eksternal. Perilaku menurut Skinner merupakan respons atau reaksi terhadap stimulus atau rangangan dari luar. Perilaku menurut Robert Kwick adalah tindakan atau perbuatan suatu organisme yang dapat dinikmati dan bahkan dapat dipelajari. 
Becker mengklasifikasikan perilaku yang berhubungan dengan kesehatan sebagai berikut:

\section{Perilaku kesehatan (health behaviour)}

Hal-hal yang berkaitan dengan tindakan atau kegiatan seseorang dalam memelihara dan meningkatkan kesehatannya. Termasuk tindakan -tindakan untuk mencegah penyakit, kebersihan perorangan, memilih makanan, sanitasi dan sebagainya.

2. Perilaku Sakit (the sick behavior)

Segala tindakan atau kegiatan yang dilakukan oleh ndividu yang merasa sakit, untuk merasakan dan mengenal keadaan kesehatannya atau rasa sakit.

3. Perilaku Peran Sakit (the sick role behavior)

Segala tindakan atau kegiatan yang dilakukan oleh individu yang sedang sakit untuk memperoleh kesembuhan.

Perilaku sehat ibu hamil yang telah disebutkan dalam buku KIA antara lain

1. Melakukan pemeriksaan kehamilan (ANC)

Perawatan kehamilan merupakan pelayanan kesehatan oleh tenaga kesehatan untuk ibu selama masa kehamilannya, dilaksanakan sesuai dengan standar pelayanan antenatal yang ditetapkan.

2. Perawatan Sehari-hari

Perawatan sehari-hari meliputi mandi 2 kali sehari dengan sabun, gosok gigi setelah sarapan dan sebelum tidur, mengelus-elus perut dan mengajak bicara bayi setelah kandungan berumur 4 bulan, hubungan suami istri yang boleh dilakukan berkonsultasi dengan petugas untuk mengetahui cara yang aman, mengurangi kerja berat, istirahat berbaring minimal 1 jam disiang hari posisi tidur sebaiknya miring menggunakan kelambu bukan obat nyamuk bakar atau semprot

3. Konsumsi Makanan Dengan Pola Gizi Seimbang

Gizi pada saat kehamilan adalah zat makanan atau menu yang takaran semua zat gizinya dibutuhkan oleh ibu hamil setiap hari dan mengandung zat gizi seimbang dengan jumlah sesuai kebutuhan dan tidak berlebihan.

4. Mengetahui Tanda Bahaya Kehamilan Dan Tanda Bayi Akan Lahir

Tanda bahaya kehamilan dan tanda bayi akan lahir penting diketahui ibu hamil maupun keluarganya.

Perawat memiliki banyak peran atau rangkaian perilaku yang bertujuan membantu individu mendapatkan derajat kesehatan yang optimal dan pada tingkat fungsi yang maksimal. 
1. Peran sebagai Pelaksana Pelayanan Keperawatan (care provider)

2. Peran sebagai Pendidik (educator)

3. Peran sebagai Perencana (Planner)

4. Peran sebagai Agen dan Pemimpin (Agent and Leader)

5. Peran sebagai Pembela (Client Advocate)

6. Peran sebagai Pengelola (Case Manager)

7. Peran sebagai Kolaborator (Colaboator)

8. Peran sebagai Penemu Kasus (Case Finder)

9. Peran sebagai Peneliti (Researcher)

Peran Gasurkes menurut koordinator Gasurkes Tingkat Kota Semarang yaitu pada upaya promotif dan preventif, diantaranya adalah mendata dan memetakan masalah ibu hamil di wilayah binaan masing-masing, mendampingi ibu hamil risiko tinggi dan mengetahui kondisi ibu hamil tersebut secara detail, mendampingi ibu hamil secara terus menerus sampai masa nifas 42 hari setelah melahirkan, memberikan penyuluhan maternal di kelas-kelas ibu hamil yang ada di wilayah binaan masing-masing, melaporkan ke Puskesmas data ibu hamil.

\section{Metode Penelitian}

Jenis penelitian ini adalah penelitian deskriptif dengan studi korelasi dengan pendekatan yang digunakan adalah pendekatan cross sectional.Penelitian ini mengetahui peran perawat sebagai petugas surveilans kesehatan sebagai variable bebas, serta perilaku sehat ibu hamil sebagai variable terikat. Populasi dalam penelitian ini adalah ibu hamil yang yang berada di 5 kecamatan yang memiliki jumlah kematian ibu tertinggi di Kota Semarang pada tahun 2015 sejumlah 636 orang, Besar sampel pada penelitian ini dengan menghitung ukuran sampel yang dilakukan dengan menggunakan rumus Slovin diperoleh sampel sejumlah 30 orang. Waktu pelaksanaan penelitian adalah bulan Mei - Juli 2017. variabel bebas dan terikat dianalisis terlebih dahulu dilakukan uji Kolmogorov Smirnov untuk menguji kenormalan data, jika normal menggunakan uji korelasi pearson, jika tidak normal menggunakan Rank spearmen.

\section{Hasil Penelitian}

Hasil penelitian dapat disajikan dengan dukungan tabel, grafik atau gambar sesuai kebutuhan, untuk memperjelas penyajian hasil secara verbal. 
Hasil penelitian ibu hamil yang masuk pada trimester $2(57,1 \%)$ dan masuk pada trimester 3 (42,9\%), didapatkan hasil bahwa 71,4 \% ibu hamil memiliki perilaku yang baik untuk melakukan pemeriksaan kehamilan, 28,6 \% memiliki perilaku yang buruk. Perilaku yang baik diantaranya adalah ibu hamil melakukan pemeriksaan kehamilan, melakukan interaksi yang baik dengan anggota keluarga, menjaga pola makan yang baik. Perilaku buruk yang dilakukan adalah ibu hamil mau periksa kehamilannya jika ada keluhan saja, adanya pantangan untuk makanan tertentu seperti buah nanas, tidak pernah mengikuti kelas ibu hamil dan senam hamil. Adanya keluhan yang muncul pada ibu hamil yaitu mual, muntah, pusing, dan bengkak kaki. Keluhan paling banyak dirasakan oleh ibu hamil adalah mual muntah sebanyak $85 \%$, sedangkan pusing sebanyak $57 \%$ dan kaki bengkak sebanyak $57 \%$. Sebanyak $40 \%$ orang ibu hamil melakukan perawatan sehari-hari seperti mandi 2 kali sehari, menggosok gigi, melakukan hubungan suami istri sesuai petunjuk dokter, 30\% lainnya mandi sehari 1 kali karena kesibukan bekerja. Ibu hamil mengetahui tanda bahaya kehamilan dan bayi akan lahir sebanyak 80\%, 20\% lainnya tidak mengetahui.Adanya keluhan pusing dan kaki bengkak merupakan indikasi faktor risiko ibu hamil yaitu peningkatan tekanan darah hingga preeklampsia. Tindakan yang dilakukan untuk menangani keluhan yang muncul $70 \%$ ibu hamil membiarkannya, lainnya segera periksa dan ada yang mengatasi dengan minum air hangat dan segera mengisi perut setelah muntah.

\section{Tabel 1}

Hubungan Peran Perawat Sebagai Petugas Surveilans Kesehatan Dengan Perilaku Sehat Ibu Hamiltugas pokok fungsi perawat dalam pendampingan ibu hamil $(n=30)$

\begin{tabular}{|c|c|c|c|c|c|c|c|c|c|}
\hline \multirow{3}{*}{$\begin{array}{c}\text { peran perawat dalam } \\
\text { pendampingan ibu } \\
\text { hamil }\end{array}$} & \multicolumn{6}{|c|}{ Frekuensi pendampingan selama 1 tahun } & \multirow{2}{*}{\multicolumn{2}{|c|}{ Jumlah }} & \multirow{3}{*}{$\begin{array}{l}\rho \text { - } \\
\text { value }\end{array}$} \\
\hline & \multicolumn{2}{|c|}{2 kali/bulan } & \multicolumn{2}{|c|}{1 kali/bulan } & \multicolumn{2}{|c|}{$\begin{array}{c}<1 \\
\text { kali/bulan }\end{array}$} & & & \\
\hline & $\mathrm{n}$ & $\%$ & $\mathrm{~N}$ & $\%$ & $\mathrm{n}$ & $\%$ & $\mathrm{n}$ & $\%$ & \\
\hline Baik & 0 & 0 & 13 & 43,3 & 0 & 0 & 13 & 43, & \\
\hline Kurang & 4 & $\begin{array}{c}13, \\
3\end{array}$ & 11 & 36,7 & 2 & 6,7 & 17 & $\begin{array}{c}56 \\
7\end{array}$ & 0,445 \\
\hline
\end{tabular}

Berdasarkan tabel 1, diketahui peran perawat yang melaksanakan tugas pokok fungsi perawat dalam pendampingan ibu hamil dengan baik dengan frekuensi 1 kali per bulan sebanyak 43,3\%, sedangkan proporsi perawat yang melaksanakan peran perawat dalam pendampingan ibu hamil dengan kategori kurang dengan frekuensi 1 kali per bulan sebanyak 
2 orang (6,7\%). Hasil uji statistik Spearman rho diperoleh nilai $\rho$-value $=0,445$ maka $\rho$-value $>0,05$, artinya tidak ada hubungan yang signifikan antara peran perawat dalam pendampingan ibu hamil dengan perilaku sehat ibu hamil.Hal ini disebabkan perbedaan kebiasaan ibu hamil yang datang ke posyandu binaan Puskesmas. Ada ibu hamil yang memilih datang langsung ke Puskesmas, tetapi ada yang datang ke posyandu. Selain itu melihat situasi pelayanan Puskesmas, ada saat perawat tidak dapat hadir bersama tim posyandu.

\section{Pembahasan}

Pada penelitian ini didapatkan gambaran bahwa sebagian besar perawat kurang berperan dalam pendampingan ibu hamil, yaitu sebesar 56,7\%. Sementara sisanya sebanyak 43,3\% mampu melaksanakan peran tersebut dengan baik. Hasil penelitian didapatkan perawat yang dapat melaksanakan peran pendampingan ibu hamil dengan baik (43,3\%). Kelompok perawat menyampaikan penyebab kurang berperannya perawat $(56,7 \%)$ dalam pendampingan ibu hamil adalah pengalaman mereka untuk mendampingi ibu hamil masih jarang dan belum pernah. Perawat terfokus dengan tugasnya di balai pengobatan menjalankan tugas pokoknya dengan jumlah pasien yang banyak dan prosedur tindakan yang lama. Sebagian besar tugas pelayanan KIA dilaksanakan oleh bidan. Keadaan tersebut menjadi kendala bagi perawat, dimana pelaksanaan pendampingan ibu hamil di Puskesmas dilaksanakan semua oleh bidan. Perawat merasa terbentur pada tupoksi yang sudah memberikan sekat pada kinerjanya dalam Perkesmas. Perawat menyatakan bahwa tupoksi kerjanya di Puskesmas tidak memiliki hubungan pendampingan ibu hamil, hal ini menunjukkan kurangnya percaya diri perawat pada kemampuannya.

Hal ini bertentangan dengan penelitian Rahmatullah, et all mengenai perawat yang bekerja di tempat terpencil dapat melaksanakan pendampingan ibu hamil dengan komprehensif termasuk penanganan persalinan, sehingga menunjukkan bahwa perawat mampu untuk melaksanakan tanggung jawab tersebut.Perawat memiliki harapan supaya diberikan ruang dan kesempatan untuk melaksanakan pendampingan ibu hamil, karena secara keilmuan perawat menguasai hal tersebut. Tanpa adanya batas dalam pelaksanaan tugas pokok fungsi dalam pendampingan ibu hamil serta lebih terstruktur. Sesuai dengan penyataan Alfredo L Fort bahwa perawat memiliki kemungkinan dalam pelaksanaan perawatan maternal, dimana prestasi nakes dipengaruhi oleh harapan kerja yang jelas, tepat waktu, lingkungan dan alat-alat yang memadai, motivasi dan insentif, pengetahuan dan keterampilan serta kapasitas untuk melakukan pekerjaan.

\section{Kesimpulan}

Perawat mampu melaksanakan sebagian perannya dengan baik sebesar 43,3\% dan sebanyak $56,7 \%$ kurang berperan dalam pendampingan ibu hamil. Peran perawat yang dapat 
dilaksanakan saat ini sebagai tenaga surveilans adalah sebagai kolaborator, educator dan case finder. Sebanyak 71,4 \% ibu hamil memiliki perilaku yang baik untuk melakukan pemeriksaan kehamilan, 28,6 \% memiliki perilaku yang buruk. Perawat masih belum optimal dalam melaksanakan perannya mendampingi ibu hamil dikarenakan ada tugas lain serta tugas pendampingan menjadi tugas pokok bidan.

\section{Saran}

Perlu adanya perhatian khusus terhadap ibu hamil untuk mencegah terjadinya kematian pada ibu hamil, program pendampingan ibu hamil oleh petugas surveilans adalah program yang perlu dipertahankan terutama adanya perawat yang menjadi bagian dalam tim gasurkes. Perawat memiliki tugas yang sama sebagai tenaga kesehatan yaitu mampu melakukan tugas pendampingan pada ibu hamil maupun nifas yang ada dimasyarakat, sehingga ibu hamil terus memiliki perilaku yang sehat.

\section{Daftar Pustaka}

Alexander-Bratcher K, Ives A, Newman L, Adams B, Davis S. Spotlight on the Safety Net. NCMedical J [Internet]. 2013;72(4):259-61. Available from: http://www.ncmedicaljournal.com/wp-content/uploads/2014/05/75317.pdf

Allender JA, Rector C, Warner KD.(2014). Community \& Public Health Nursing : Promoting The Public's Health. Philadelphia: Lippincott Williams \& Wilkins.

Aritonang, E.(2010).Kebutuhan Gizi Ibu Hamil. Bogor : IPB Press.

Asmadi. (2008). Konsep Dasar Keperawatan. jakarta: EGC

BPKB Jawa Timur. Modul Pendampingan Tahun 2017. 20 Februari 2017. http://www.damandiri.or.id/file/muzaqiunairbab2.pdf

Dharma, Kelana Kusuma.(2011).Metodologi Penelitian Keparawatan Panduan Melaksanakan dan Menerapkan Hasil Penelitian.Jakarta : CV Trans Info Media.

Dinas Kesehatan Jawa Tengah.(2015). Kebijakan Pemerintah Provinsi Jawa Tengah Dalam Peningkatan Peran Serta Masyarakat Dalam Upaya Penyelamatan Ibu Melahirkan Dan Bayi Baru Lahir. Semarang: Dinkes Jateng.

Dinas Kesehatan Kota Semarang.(2015). 119.2.50.170:9090/sim-oprec Dinas Kesehatan Kota Semarang. Semarang: Dinkes.

Dinas Kesehatan Kota Semarang. (2015).Laporan Tahunan Bidang Kesehatan Keluarga Tahun 2015. Semarang: Dinkes Kota Semarang. 
Dinas Kesehatan Provinsi Jawa Tengah. (2015).Buku Pedoman Pelaksanaan Pendampingan Ibu Hamil bagi Mahasiswa One student One Client (OSOC): Untuk Mahasiswa Keperawatan. Semarang: Dinas Kesehatan Provinsi Jawa Tengah.

Dirjen Bina Gizi KIA Kementerian Kesehatan RI. Kesehatan Dalam Rangka Sustainable $\begin{array}{lllll}\text { Development } & \text { Goals } & \text { (SDGs). } & 24 & \text { April }\end{array}$ http://www.pusat2.litbang.depkes.go.id/pusat2_v1/wp-content/uploads/2015/12/SDGsDitjen-BGKIA.pdf

Dita Anugrah Pratiwi. Angka Kematian Ibu di Indonesia Masih Jauh Dari Target MDGs 2015. 17 Juni 2016. http://www.kompasiana.com/ditaanugrah/angka-kematian-ibu-diindonesia-masih-jauh-dari-target-mdgs-2015_54f940b8a33311ba078b4928

Helvie CO. (2013). Advanced Practice Nursing in The Community. London: Sage publication Inc.

Helvie CO. (2013).Advanced Practice Nursing in The Community. London: Sage publication Inc;

Hutahaean, Serri. (2013).Perawatan Antenatal. Jakarta : Salemba Medika.

Indriyani , Diyan., \& Asmuji. (2014). Buku Ajar Keperawatan Maternitas Upaya Promotif dan Preventif dalam Menurunkan Angka Kematian Ibu dan Bayi. Yogyakarta: Ar Ruzz Media.

Indriyani , Diyan., \& Asmuji. (2014). Buku Ajar Keperawatan Maternitas Upaya Promotif dan Preventif dalam Menurunkan Angka Kematian Ibu dan Bayi. Yogyakarta: Ar Ruzz Media.

Kementerian Kesehatan Republik Indonesia. (2016).Profil Kesehatan Indonesia 2015. Jakarta: Kemenkes RI.

Kementerian Kesehatan RI.(2011). Buku Kesehatan Ibu dan Anak. Jakarta: Kementerian Kesehatan dan JICA (Japan International Coorperation Agency).

Kementerian Kesehatan RI. (2011).Buku Kesehatan Ibu dan Anak. Jakarta: Kementerian Kesehatan dan JICA (Japan International Coorperation Agency).

Menteri Kesehatan RI. (2003).Keputusan Menteri Kesehatan Republik Indonesia Nomor 1116/Menkes/Sk/Viii/2003. Tentang Pedoman Penyelenggaraan Sistem Surveilans Epidemiologi Kesehatan.

Mitayani,Sartika.W. (2010).Ilmu Gizi.Jakarta:Trans Info Media.

Notoatmodjo S,. (2007).Ilmu Kesehatan Masyarakat. Jakarta: Rineka.

Soerjono Soekanto. Sosiologi Suatu Pengantar. Jakarta: Raja Grafimdo Persada.2002. 